\title{
IMPACT OF PRICE PROMOTION ON BRAND EQUITY MODEL: A STUDY OF ONLINE RETAIL STORE BRANDS
}

\author{
Dr. S. S. Bhakar \\ Director, Prestige Institute of Management, Gwalior, MP, India \\ Dr. Shilpa Bhakar \\ Associate Professor, Prestige Institute of Management, Gwalior, MP, India \\ Dr. Shailja Bhakar \\ Associate Professor, Prestige Institute of Management, Gwalior M.P., India
}

\begin{abstract}
The study evaluates the effect of Price Promotion strategy (PPs), extensively used by online stores to promote sales and improve market share, on Brand Equity (BE) elements of these stores. The study focuses on the mediating role played by the two prominent elements of $\mathrm{BE}$, perceived quality $(\mathrm{PQ})$ and brand awareness(BA) in forming the relationship between the PPs on brand association (BAsso) and brand loyalty (BL) in case of online stores (Amazon, Flip Kart, Snap Deal). The data for the study was collected from the students of graduate and post graduate programs at Gwalior, Madhya Pradesh (India) selected on the basis of random sampling method. The causal relationships between PPs and the elements of BE along with moderating effects of PQ and BA on the relationships of PPs on BAsso. and BL were evaluated using SEM methodology. PPs contribute positively to all the four elements of $\mathrm{BE}(\mathrm{PQ}, \mathrm{BA}, \mathrm{BAsso}$. and $\mathrm{BL})$. The study has thus, made significant contribution to the existing literature that unlike physical stores, in case of online stores, PPs contribute in improving all the elements of BE instead of having adverse effect. The study has made another very important contribution to existing literature in evaluating the mediating role played by $\mathrm{PQ}$ and BA. The results indicate that PQ fully mediates the relationships of PPs with BAsso. and BL. Similarly, BA fully mediates the relationships of PPs with BAsso. and BL.
\end{abstract}

Keywords: Price Promotion, Brand Equity, Brand Awareness, Perceived Quality, Brand Association, Brand Loyalty.

\section{INTRODUCTION}

Brand equity is the overall value that the customers attach to a brand. Major contributors to research on branding have conceptualized brand equity on the basis of consumer perspective (Aaker, 1991, Keller, 1993 and Christodoulides et al. (2010) or on financial perspective (Sullivan, 1993 and Haigh, 1999). Proponents of Customer based brand equity have also differed in identifying the components of brand equity and the factors affecting brand equity. Majority customer based perspective identified $B L, B A$, BAsso and PQ (Aaker, 1991; Yoo and Donthu, 2001;Konecnik and Gartner, 2007; Gill and Dawra, 2010). Some other researchers used additional constructs such as customer satisfaction (Kim et al. 2008), brand image (Keller, 1999), organizational associations (Sinha et al. 2008) brand trust and brand commitment (Marquardt, 2013) as components of BE. Research on factors affecting customer based brand equity have identified PP (Vidal and Ballester, 2005), brand attitude (Faircloth et al. 2001), brand ambassador credibility (Dwivedi and Johnson, 2012), Event Marketing (Zarantonello and Schmitt, 2012) as predictors of BE. Therefore, many business organizations invest a lot of money on marketing communication, such as price promotion (PP) with a hope of attaining high brand equity (BE). PPs are most commonly used as to attract consumers and increase sales. Companies usually use $\mathrm{PP}^{\prime} \mathrm{s}$ to stimulate sales, increase trials, attract budget conscious buyers, retain loyal customers, or provide increased value perception (Huff \& Alden, 2000). However, the question is whether PP methods increase BE of a product. Raghubir \& Corfman (1999) confirmed that $\mathrm{PP}^{\prime} \mathrm{s}$ provide an economic incentive to customers in order to purchase a brand.

The studies evaluating effect of PPs on consumer brand evaluations can be placed in three groups. First group includes studies that 
have depicted positive effects of PP's on $\mathrm{BE}$ elements (Kuehn \& Rohloff, 1967; Cotton \&Babb, 1978; Bawa \& Shoemaker, 1987; Rothschild \& Gaidis, 1981 and Lattin \& Bucklin, 1989). Studies in the second group have shown negative effects of $\mathrm{PP}^{\prime} \mathrm{s}$ on $\mathrm{BE}$ elements (Davis et al., 1992; Ehrenberg et al., 1994; Morais et al., 2006; Mullin \& Cummins, 2008; Campo \& Yague, 2008) whereas the studies in the third group have identified insignificant or no effect of PPs on BE elements (Neslin and Shoemaker, 1989;Davis, Inman, and McAlister, 1992; Bravo, Andres \& Salinas, 2007; Sriram et al., 2007).

Online retail stores use price promotions in a big way to increase sales and market share. In physical stores case, price promotions used extensively, may adversely affect their perceived quality and in turn brand loyalty. Does PP strategy affect PQ and BL in case of online stores also in the same way as it does in case of physical stores. Therefore, evaluating the effect of PP strategies on components of BE in case of online stores is vital. Thus, there is a need of an in depth study to evaluate the effect of PP on overall equity of a brand and its elements, BA, BL, PQ and Basso in online stores case. Current study evaluates the effect of PP strategies used by online stores (Flipkart, Amazon and Snapdeal) on their BA, PQ, BL and BAsso. Promotion efforts of companies lead to higher degree of knowledge of the brand (awareness and PQ) (Villarejo et. al., 2005) but the ultimate objective of these promotions is to increase their customer base and improve BE. Accordingly, the current paper models the impact of PP on BL mediated by PQ and BA also the impact of PP on BAsso mediated by $\mathrm{PQ}$ and $\mathrm{BA}$ in case of online stores. The study will evaluate the following conceptual model:

\section{Conceptual Model}

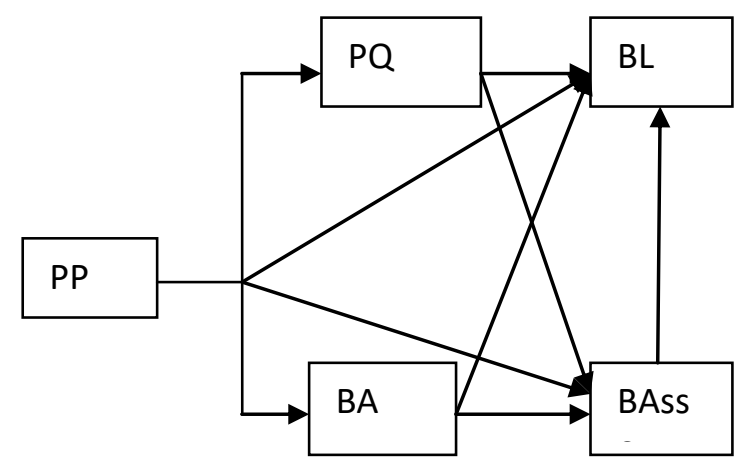

\section{LITERATURE REVIEW \\ PP - BE}

The impact of PP on BE has been studied by various researcher but results are contradictory. Some researchers have confirmed negative impact (Jedidi et al., 1999; Yoo et al., 2000; Mullin \& Cummins, 2008; Buil et. al., 2010; Selvakumar \& Vikkraman, 2011). Ramos \& Franco (2005) studied the relationship in washing machine product category. They found that price incentives used for uplifting sales affect the established reference price levels and have negative impact on BE. The authors demonstrated a negative relationship between price deals and BE. From strategic perspective also price deals show negative effect as it diminishes BE (Yoo et al., 2000). If a product is over-promoted, consumers will buy less of the product at the regular price and wait for PPs. In other words, PPs can reduce the consumer's reference price, which in turn results in lowered BE (Lattin \& Bucklin, 1989; Mayhew \& Winer, 1992). A stream of literature also shows that PPs can persuade consumers to postpone their purchase decision and wait for a lower price in the future (Assunção\& Meyer, 1993; Kalyanaram \& Winer (1995); Mela et al. (1998) which will have negative effect on BE.

PP is found to have positive effect on BE (Vidal \& Ballester, 2005; Chu and Keh, 2006; Melina and Evelyn, 2011). In tobacco industry information delivered to customers (related to a particular brand), through promotional methods is considered as an important variable that affect the equity of these brands positively (Marcel, 2009). In Indonesian beverage industry (Nurcahya, 2014) found positive effect of PP programs on three elements of BE i.e. PQ, BL and BAsso. To have this positive effect on brand equity marketers must design creative promotional campaigns. It is not necessary that while using price promotion technique organizations need to give 'one on one', $50 \%$ off, or pay less get more. Rather than providing on the spot financial benefit it is recommended that organizations should try out methods of price promotions which help in building long term relationships with the customers such as coupon discount on next purchase, price discount to other customer recommended by the first one or a chance of winning a trip, etc. These types of PP techniques will keep the customers close to the brand for longer time 
which in turn will increase BA, if satisfied, increasing $\mathrm{BL}$ and up lifting brand equity.

Some investigators found that the effect is statistically insignificant (Ehrenberg, Hammond \& Goodhardt, 1994; Sriram et al., 2007; Gil et al., 2007). Kuntner (2017) studied the effect PP on different BE level brands. $\mathrm{He}$ distinguished brands on the basis of initial equity levels (like high, moderate and low initial equity brands). He concluded that for low-equity brands, PP strategies have close to zero effect, but for higher initial equity level brands the effect is highly negative. He also demonstrated that the negative influence of PPs on the brand's equity is proportionate to the increase in initial BE level. Thus, higher initial equity brands should avoid using PPs and low equity brands can use PP deals to attract new customers, non-users, or competitor brand customers(Ardestani, et al., 2014).

Review of literature explains that PP can affect BE positively as well as negatively, depending on product category, level of initial equity, brand positioning, target segment, etc. Thus, marketers must analyze all these factors before deciding to go for PP strategy.

\section{PP - PQ}

PP strategy is used by organizations to attract non buyers, increase sales, increase market share and to attract customers of competitor brands. Buil et al., (2013) have explained that if PP strategy is introduced in the market in such a way that it is perceived as value for money by the customers then it could bring about a positive effect on brand evaluation. In contrast it is also possible that customers perceive that products of inferior quality are promoted through PP thus price discounts may negatively affect consumers' quality perceptions (Rao \& Monroe, 1989; Madan \& Suri, 2001; Agarwal \& Tea, 2002).

Various models developed by researchers indicate that price-quality based strategies are a double edged sword. It can have both positive as well as negative effect on brands (Milgrom \& Roberts, 1986; Jedidi et al., 1999; Ramos \& Franco, 2005). The prevailing theory, which says that price can serve as a quality indicator, hinges on the consumers' belief that if something costs more, then it must be better. If organizations want to take advantage of this belief than they should set "quality-assuring" price which should be a protection price for both organization and a value for money for the customers (Klein \& Leftler, 1981). As if customers feel that a firm is trying to sell a product for less than the quality-assuring price, then it will lead to a low quality impression about the product (Bagwell \& Riordan, 1991; Kirmani \& Rao, 2000).

Given that informed consumers purchase from high-quality sellers and uninformed consumers purchase from both high- and lowquality sellers, the literature shows that uninformed consumers can get a price-quality reference point from the informed consumers (Chan \& Leland, 1982; Cooper \& Ross, 1984). In addition, previous studies have also provided evidence of a strong contribution of price in developing PQ (Dodds et al., 1991; Erdem et al., 2002; Ramos \& Franco, 2005).

Huang et al., (2014) studied the effect of PPs on customer's PQ and repeat purchase intentions. They predicted a positive impact of PPs on PQ and customers' repeat-purchase intentions. They also identified that gender and consumption frequency does not demonstrate a moderating effect.

Vecchio et al., (2007) evaluated the long term effect of PPs on brands PQ. They found that in long run frequent use of PPs can have negative influence on brands PQ. This effect might not be significant after one PP but if repeated several times it could change the consumer's reference point because products with lower price are considered to have poorer quality (Ophuis \& Trijp, 1995; Alba et al., 1999). Villarejo \& Sanchez, (2005) posited that PPs are perceived as short-term benefits by the consumer; they contribute to lower quality perceptions in the long-term.

In contrary Waanders (2013) evaluated the effect of deep $\mathrm{PP}^{\prime}$ s on store brand and high end brand of wheat bears and found out that deep $\mathrm{PP}^{\prime} \mathrm{s}$ could also have a positive effect on brand name and $\mathrm{PQ}$. But to get that positive effect BA needs to be high. This research also explained that deep $\mathrm{PP}^{\prime}$ s positively influenced the taste experience of the high end brand but negatively influenced the taste experience of store brands. Therefore, in the long run PPs could influence the PQ of the store brand negatively (Ophuis \& Trijp, 1995). Based on 
the above evidence from the literature hypothesis 1 has been set up.

Hypothesis 1:PP contributes significantly to PQ

\section{PP - BA}

Researchers and organizations have continuously worked on to understand the effect of different promotional techniques on BA level of their brands in various industries so as to identify the most appropriate promotion package in order to achieve maximum BA of their respective brands. Villarejo, et. al. (2005) evaluated the direct and indirect effect of the marketing strategies on BA. They indicated that the marketing efforts of the companies significantly increase brand awareness, and thus enhance the probability of brand recall at the time of actual purchase. Piratheepan \& Pushpanatha (2013) evaluated the effect of different promotional techniques (advertising, sales promotion, direct marketing, etc) on BA in milk powder industries. They found that all forms of marketing efforts have positive effects on BA, but in comparison to advertising and sales promotion the impact is less significant in case of personal selling and direct marketing. Thus, in milk powder industry sales promotion (PPs, coupons, etc) will help in increasing BA.

Gilbert \& Jackaria (2002) evaluated specifically the effect of 'get one free unit on purchase of one unit' promotion techniques on BA. They concluded that this type of promotional technique may not affect BA before first time purchase, but once the customer evaluates the product and finds the deal fair enough, it will enhance the chances of better brand recall for future purchases. Nurcahya (2014) also did not find any significant impact of PP on BA. Shelvakumar and Joshna found positive effect of PP on BA in case of Banking and no effect of $\mathrm{PP}$ on BA in case of fast food restaurants. Based on the above discussion of literature hypothesis 2 is framed.

Hypothesis 2:PP contributes significantly to BA

PP - BL

Earlier models depicted that consumers want to establish loyalty towards a specific brand, but recent studies concluded that due to rise in literacy rates and easy access of information, customers have become choosier and evaluative in terms of value for money (Jing \&
Wen, 2008; Koçaş \& Bohlmann, 2008). Thus, organizations can use promotional tactics including PPs to attract these evaluative customers and retain them through timely rewards (Raju et al. 1990; Rao 1991). Eisman, (1990)has also concluded that use of promotions helped organizations in stimulating the purchase intention of customers and retaining customers through various incentives. Pressey \& Matthews, (1998) have stated that the probability of a shopper to switch from normal brand to competitor brand increases by fifty percent if it is on promotion. Price deals may motivate consumers to make purchase and if satisfied, then repeat purchases (Marcel, 2009), but here the loyalty is Pseudo-Loyalty because when the campaign is over, consumers interest in the brand decreases gradually. Nevertheless, PP encourages customers to try new products and if they are satisfied, it may lead to repurchase and a positive outlook towards the brand.

Anderson \& Kumar (2007) identified that if organization is targeting price sensitive market then they should promote more often and deeper, as the price-sensitive segment gets positively affected by the level and repetition of the discount. While studying online books selling data Koçaş \& Bohlmann (2008) revealed that the frequency of promoting weaker brands is low with high discounts whereas for stronger brands this strategy doesn't work. For stronger brands frequent but smaller PP's result in higher degree of BL. In manufacturing industry also, weaker brands use promotions to retain their loyal customers, as a defensive strategy whereas on the other hand stronger brands use promotions to attract loyal customers of the weaker brands (Raju et al., 1990).

It is widely accepted that PPs can enhance sales immediately, by stimulating consumer trials, some of whom might become repeat buyers (Ehrenberg et al., 1994). Selvakumar and Joshna (2011) found significant effect of PPs on BL for Banking and fast food restaurant brands. Hendra and Budi (2017) and Chi Yeh and Yand (2019) also reported positive effect of PPs on BL. Based on the evaluation of the above literature hypothesis 3 is formulated.

Hypothesis 3: PP contributes significantly to BL 


\section{PP - BAsso}

A brand's price is not only a financial tag associated with it. It is as much important as brand name, logo, packaging or endorser of the brand. Price of a product in comparison to competing products, moderate the Brand Image a customer has in mind. Thus, before introducing a PP strategy, marketers must analyze the influence PPs will have on their brand image and other Brand Associations and how strong this influence will be? Selvakumar and Joshna (2011) reported that PPs contribute significantly in enhancing BAsso in case of established strong brands such as banks where as PPs have no effect on BAsso in case of fast food restaurants.

Winer (1986) concluded that PP has a negative significant effect on BAsso because $\mathrm{PP}^{\prime} \mathrm{s}$ conveys an image of low and unstable quality. So if PP's are used, then it should be kept in mind that they are in line with the desired positioning strategy. If a value positioning is chosen, that promises high quality at low price then marketing team must ensure that in order to minimize the price quality is not compromised. But if organization wants to establish its brand as a high end brand then they need to be cautious while using PP strategy because many a times it has turned sour and affected the other Brand Associations negatively (Stibel, 2008). Based on the above evaluation of literature hypothesis 4 is formulated.

Hypothesis 4:PP contributes significantly to BAsso

Basso - PQ and BL

Literature survey on the relationship between BAsso and BL has indicated mixed results. Some studies have found significant positive effect of Basso on BL (Falahat et al. 2018) based on a study carried out on hardware retail stores in Malasia and Alhaddad, (2015) based on a study done on sports wear retail stores. Erfan and Choon (2013), Severi and Ling (2013) also found strong positive relationship between BAsso and BL. On the other hand Kieu (2016), Chinomona and Maziriri (2017) did not find any effect of BAsso on BL based on a study completed on shopping malls in Vietnam. Based on the above review of literature following hypothesis 5 and 6 are framed:
Hypothesis 5: BAsso significantly contributes to BL

Hypothesis 6:BAsso contributes significantly to $\mathrm{PQ}$

\section{$B A-B L$ and $P Q$}

The findings of previous studies have indicated mixed results on the relationship between BA and BL. Conceptually BL is not possible without the awareness of the customers about the brand. Oh (2000) reported insignificant positive relationship between BA and PQ. Chinomona and Maziriri (2017) found insignificant relationship bitween BA and BL where as Malik, Gafoor and Iqbal (2013), Jing, Pitsaphol and Shabbir (2014), Dhurup, Mafini and Dumasi (2014), Xu, Li and Zhou (2015), Hendra and Budi (2017) found positive relationship between $\mathrm{BA}$ and $\mathrm{BL}$ in their studies. Hussain et al. (2017) found significant positive effect of BA on BL and BAsso for users and non users both in a study conducted on mobile phone brands. Chi, Yeh and Yang (2009) reported positive significant positive effect of BA on BL and PQ. Therefore, looking at the empirical evidence hypotheses 7 and 8 are framed:

Hypothesis 7: BA contributes significantly to BL

Hypothesis 8: BA significantly contributes to PQ

\section{BA and BAsso as Mediators}

Shintaputri, and Wuisan (2017) did not find BA as mediator of relationship between PP and BL in a study carried out on a well known mobile brand. However, Beneke, Flynn, Greig, \& Mukaiwa (2013), Buditama \& Aksari (2017) reported that the PP-BL relationship is partially mediated by BA. The authors did not find any research work that evaluated $P Q$ as mediator of PP-BAsso relationship.

Hypothesis 9: BAsso significantly mediates the relationship between PP and $\mathrm{BL}$

Hypothesis 10: BAsso significantly mediates the relationship between PP and PQ

Hypothesis 11: BA significantly mediates the relationship between $\mathrm{PP}$ and $\mathrm{BL}$

Hypothesis 12: BA significantly mediates the relationship between PP and PQ

\section{RESEARCH METHODOLOGY}

We evaluated the causal effect of PP on BL and BA with $\mathrm{PQ}$ and BA acting as mediating variables on online stores (Flip Kart, Amazon, 
Snap Deal). Survey method was used for collecting the data for the research. The study was done to evaluate the effect of price promotions on the elements of brand equity and to evaluate the mediating role of PQ and BA.

The research was conducted using UG and PG students studying in various Institutions located at Gwalior region in the state of Madhya Pradesh (India) as respondents. The students who attended the Institutions during the data collection phase formed the sample frame for the study (Lim \& Ting, 2012). Since the Institutions were not ready to provide the complete list of students and their contact details, the students were selected for the study based on non probability quota sampling method. Equal number of male and female students was selected for providing responses. The data was collected after meeting the respondents face-to-face. In all 350 questionnaires were distributed to the students for collecting responses. All the 350 questionnaires were collected and 325 questionnaires were found with responses on all the statements. Thus, the final sample size was 325 (Klenke, 2008).

StandardizedQuestionnaires of PQ, BL, BA, BAsso, as well as PP, proposed by Nurcahya (2014) were used for data collection. 7-point Liker type scale was used for data collection. Cronbach's alpha is a prominent tool for evaluating internal consistency reliability for the measures (Perry, 2001; Rogelberg, 2002). Cronbach's Alpha coefficient of reliability was computed to establish the reliability of all the measures used in the study.

EFA was used to identify the factors underlying the measures. Principle Axis Factoring (PAF) (Conway \& Huffcutt, 2003) was applied to identify factors of the measures (Fabrigar et al. 1999; Beavers et al. 2013).

PLS-SEM is preferred over CB-SEM in evaluating predictive causal relationships in a complex model (Rigdon, 2012, 2014). Also PLS-SEM uses better algorithm for evaluating descriminent validity (Franke and Sarstedt, 2019). Therefore, PLS-SEM was used to test the structural model as the model comprising of five variables and 19 indicators was complex and causal relationships were evaluated.

\section{RESULT AND DISCUSSION}

Nunally's (1978); Lance, Butts \& Michels (2006) Identified necessary conditions for considering a measure as reliable and stated that reliability coefficient values above 0.7 indicate that the measure is Reliable. Table 1 displays the Cronbach's Alpha values for all the measures. It is evident that all the coefficients are higher than 0.7; therefore, all the measures are reliable.

KMO values need to be higher than 0.5 for the data to be from a sample that is large enough for factor analysis. Table 2 shows the $\mathrm{KMO}$ values for all the measures. It is evident that all the KMO values are higher than 0.5 indicating that the sample was adequate for Exploratory Factor Analysis (EFA). The Bartlett's test compares the computed item-to-item correlation values with the correlations in identity matrix. The two matrices must be different for the data to be suitable for EFA. Table 2 also indicates that the Chi Square test values are significant at 0.0 level of significance indicating, that the item-to-item correlation matrices for all the measures are not identity matrices. Therefore, the data obtained through all the variables are suitable for EFA.

\section{Exploratory Factor Analysis (EFA)}

EFA was conducted using Principle Axis Factoring for convergence and Varimax for rotation on $\mathrm{PQ}, \mathrm{BL}, \mathrm{BA}, \mathrm{BAsso}$ and $\mathrm{PP}$ to identify the underlying factors of the measures. All the measures of the study converged on single factors only; therefore, the names of the variables were used for representing the factors.

\section{Structural Equation Modeling Results}

The Structural model consisting of variables; Price Promotion (PP), Brand Awareness (BA), Service Quality (SQ), Brand Association (BAss), Brand Loyalty (BL) was tested using Smart PLS (Fig.1). These variables were measured using a number of items (indicators). Since EFA converged on single factors for all the variables, structural model was constructed using five variables with their sixteen indicators. 
Although computing goodness of fit indices is not essential for SEM models tested using Smart PLS. Some of the selected goodness of indices are used to demonstrate that the model had high goodness of fit (Table 3).

\section{SRMR (Standardized Root Mean Square} Residual)- The value of SRMR need to be below 0.08 for the model to have high fit with data (Hu and Bentler, 1999). The computed value for SRMR is 0.058; showing that the model has high goodness of fit.

2. NFI (Normed Fit Index) - The value of NFI should be greater than 0.9 for the model to have goodness of fit (Lohmöller, 1989). The computed value of NFI is 0.917 . Thus, the model has high goodness of fit.

\section{Convergent Validity}

Convergent validity indicates the relationship between indicators of a variable (Carmines and Zeller, 1979). Three parameters of the model indicate whether the variables have convergent validity. The parameters are: Factor Loadings (Outer Loadings), Construct Reliability (CR) and Average Variance Explained (AVE).

\section{Outer Loadings}

The model consists of five variables interrelated as indicated in the model diagram (Fig. 1) along with their indicators. The outer loadings indicate the factor loads of all the indicators on their variables. The loadings must be higher than 0.7 or very close to them. All the indicators in the current model have are higher than 0.7 other than one indicator of Brand Awareness, which has a loading of a 0.683 that is very close to 0.7 (Table 4 ). Thus, the first criterion for convergent validity is satisfied.

\section{Composite Validity (CV)}

The second criteria for establishing $\mathrm{CV}$ is construct reliability (CR). The $\mathrm{CR}$ of all the variables must be higher than 0.7 for demonstrating CV. However, the value higher than 0.6 are acceptable if the research is exploratory in nature (Bagozzi and Yi, 1988). Table 5 displays CRs for all the variables. Since all the CR values are greater than 0.8 , the second criterion for convergent validity is also fulfilled.

\section{AVE}

The third and final criterion for establishing convergent validity is the AVE. According to Fornell and Larcker, 1981, AVE evaluates the average variance that a construct extracts from its indicators in comparison to measurement error calculated for each variable. According to Bagozzi \& Yi (1988) and Chin (1998) the values of AVE should exceed 0.5; that means the variables are able to extract at least $50 \%$ of the total variance. Therefore, AVE values above 0.5 fulfill the third criteria for high convergent validity. As displayed in the table5, all the AVE values are higher than 0.5. Thus, the third criterion for the convergent validity of all the variables of the study is also fulfilled. In other words, the variables included in the model have high convergent validity.

\section{Discriminant Validity}

As the convergent validity indicates homogeneity of variables of a construct the discriminant validity demonstrates the separation/differentiation of each constructs from the other constructs of the model (Carmines and Zeller, 1979). The discriminant validity is demonstrated by AVE values that are higher than 0.5. All the AVEs should be higher than all the interconstruct correlations (Chin, 1998). Square Root of AVEs are placed on the diagonal and the inter-construct correlations are placed on off diagonal cells in the matrix. If the diagonal elements are higher than the off diagonal values in the corresponding rows and columns the discriminant validity is established. Therefore, discriminant validity is established for this model as all the diagonal values are higher than off diagonal values in the corresponding rows and columns (Table 6).

\section{Hypothesis Testing}

In structural models the hypotheses are tested by computing path coefficients $(\beta)$. The path coefficients in SEM indicate causal relationship between the constructs (Wixom and Watson, 2001). Table 7 shows hypothesized path coefficients $(\beta)$.

\section{Bootstrapping}

Although the coefficient $\beta$ values indicate causal relationship they are not sufficient to indicate whether this relationship is significant. Bootstrapping procedure evaluates 
whether these relationships are significant (Chin's, 1998). Bootstrapping with 500 subsamples was performed to evaluate whether the relationships between constructs were significant. Boot strapping computed t-statistic for each path coefficient ( $\beta$ ). If the $t$ - statistic value was 1.96 or greater, the hypothesis was considered supported, otherwise the hypothesis was not supported. Table-7 shows $t$ statistics values for all the inter-construct relationships.

SEM diagram with t-values computed using Bootstrapping procedure is displayed at fig- 2 .

Hypothesis 1:PP contributes significantly to BAsso

The hypothesis was tested through computation of path coefficient beta $(\beta)$. The computed $\beta$ value between PP and BA was 0.614 . The standardized $\beta$ was tested through computation of $\mathrm{t}^{\prime}$ statistic. The value of $\mathrm{t}^{\prime}$ was 10.920 significant at .000 level of significance. Thus, the null hypothesis is supported. Tebebe and Singh (2016) found significant effect of PP on BAsso in a study on Brewery Industry.

Hypothesis 2:PP contributes significantly to BA

The hypothesis was tested through computation of path coefficient beta $(\beta)$. The computed $\beta$ value between PP and BA was 0.641 . The standardized $\beta$ was tested through computation of ' $t$ ' statistic. The value of ' $t$ ' was 10.872 significant at .000 level of significance. Thus, the null hypothesis is supported. Tebebe and Singh (2016) found significant effect of Monetary (Price) Promotion on BA in a study on Brewery Industry. Rungtrakulchai (2015) also found strong causal relationship between PP and BA in a study on luxury Brands.

Hypothesis 3:PP contributes significantly to BL

The hypothesis was tested through computation of path coefficient beta $(\beta)$. The computed $\beta$ value between PP and BL was 0.115 . The standardized $\beta$ was tested through computation of ' $t$ ' statistic. The value of ' $t$ ' was 1.732 significant at .084 level of significance. Thus, the null hypothesis is not supported. Results are in line with the findings of Rungtrakulchai and Nichi (2015) where they did not find any causal relationship between PP and BL in a study on luxury Brands.

Hypothesis 4:PP contributes significantly to PQ

The hypothesis was tested through computation of path coefficient beta $(\beta)$. The computed $\beta$ value between PP and PQ was 0.251 . The standardized $\beta$ was tested through computation of ' $t$ ' statistic. The value of ' $t$ ' was 3.728 significant at .000 level of significance. Thus, the null hypothesis is supported.

Hypothesis 5:PQ significantly contributes to BL

The hypothesis was tested through computation of path coefficient beta $(\beta)$. The computed $\beta$ value between PQ and BA was 0.398 . The standardized $\beta$ was tested through computation of ' $\mathrm{t}$ ' statistic. The value of ' $\mathrm{t}$ ' was 5.152 significant at .000 level of significance. Thus, the null hypothesis is supported. Loureiro (2013) also found similar results while evaluating the effect of $\mathrm{PQ}$ on $\mathrm{BL}$ in a study on Internet Banking. Alhaddad (2015) found significant effect of $\mathrm{PQ}$ on $\mathrm{BL}$ in a sports wear study. Chinomona and Maziriri (2017) also reported positive contribution of $\mathrm{PQ}$ on BL.

Hypothesis 6: BAsso contributes significantly to PQ

The hypothesis was tested through computation of path coefficient beta $(\beta)$. The computed $\beta$ value between BAsso and PQ was 0.214 . The standardized $\beta$ was tested through computation of ' $t$ ' statistic. The value of ' $t$ ' was 2.859 significant at .004 level of significance. Thus, the null hypothesis is supported. Alexandris et al. (2008) reported similar findings based on a study on fitness clubs.

Hypothesis 7: BAsso significantly contributes to BL

BAsso does not contribute significantly to BL as indicated by the path coefficients value $(\beta)$ $=0.117$. The relationship is tested using $\mathrm{t}-$ statistic; the value of $\mathrm{t}$ is 1.737 , significant at $8.3 \%$ level of significance. Result is in contrast with the findings of Homburg et al. (2010), Chen, Yeh and Jheng (2013) and Hussain et al. (2017) where in the authors found significant effect of BAsso on BL in their study on personal computer industry. 
Hypothesis 8: BA contributes significantly to BL

BA contributes significantly to BL as indicated by the path coefficient $(\beta)=0.233$. The path coefficient is tested for significance using $t$ test. The value of t-test statistic is 2.831, significant at $0.5 \%$ level of significance. Thus, the hypothesis is supported. Similar results were obtained by Abbas (2019) where the authors found significant effect of BA of higher Education Institutions on their BL. Dhurup, et. al. (2014) also found significant causal relationship of BA on BL in a study on Retail outlets. The results of Malik et al. (2013) also found strong positive relationship of BA on BL in a service sector study providing support to the finding of this study.

Hypothesis 9: BA contributes significantly to PQ

BA has significant affect on PQ. The relationship was tested through the path coefficient $\beta$. The value of $\beta$ was 0.316 ; tested through computation of ' $\mathrm{t}$ ' $=4.842$ significant at $0 \%$ level of significance. Therefore the hypothesis is supported.

\section{Mediation Effect}

Hypothesis 10: PQ significantly mediates the relationship between $\mathrm{PP}$ and $\mathrm{BL}$

Mediation effect of $\mathrm{PQ}$ on the relationship between PP and BL was evaluated through computation of indirect effect of Price Promotion on Brand Loyalty. The total indirect effect of PP on BL is evaluated through computation of standardized $\beta$; the value of $\beta$ was 0.104 . The standardized $\beta$ was tested through computation of ' $\mathrm{t}$ ' statistic; the value of ' $t$ ' was 2.520, significant at 0.012 . Thus, the null hypothesis if supported. The PQ significantly mediates the relationship between PP and BL. Saif et al. (2019) also found that PQ fully mediated the relationship between PP and BL in a study on Apparel Industry, thus supporting the results of this study.

Hypothesis 11: PQ significantly mediates the relationship between $\mathrm{PP}$ and BAssso

Mediation effect of $\mathrm{PQ}$ on the relationship between PP and BAsso was evaluated through computation of indirect effect of PP on BAsso. The total indirect effect of PP on BAsso was evaluated through computation of standardized $\beta$; the value of $\beta$ was 0.244 . The standardized $\beta$ was tested through computation of ' $\mathrm{t}$ ' statistic; the value of ' $\mathrm{t}$ ' was 5.095, significant at 0.000 . Thus, the null hypothesis if supported. The PQ significantly mediates the relationship between PP and BAsso.

Hypothesis 12: BA significantly mediates the relationship between PP and BL

Mediation effect of BA on the relationship between PP and BL was evaluated through computation of indirect effect of PP on BL. The total indirect effect of PP on BL is evaluated through computation of standardized $\beta$; the value of $\beta$ was 0.287 . The standardized $\beta$ was tested through computation of ' $t$ '; the value of ' $t$ ' was 5.793 , significant at 0.000 . Thus, the null hypothesis if supported. The BA significantly mediates the relationship between PP and BL.

Hypothesis 13: BA significantly mediates the relationship between PP and BAsso

Mediation effect of BA on the relationship between PP and BAsso was evaluated through computation of indirect effect of PP on BAsso. The total indirect effect of PP on BAsso is evaluated through computation of standardized $\beta$; the value of $\beta$ was 0.183 . The standardized $\beta$ was tested through computation of ' $t$ ' statistic; the value of ' $t$ ' was 3.461, significant at 0.001 . Thus, the null hypothesis if supported. The BA significantly mediates the relationship between $\mathrm{PP}$ and BAsso.

We could not locate any study that evaluated the mediating role played by $\mathrm{PQ}$ on the relationship between PPs and BAsso. Similarly, we did not find any study that evaluated the mediating role played by BA on the relationship between PPs with BAsso. and BL.

\section{IMPLICATIONS \& CONCLUSION}

The study has found significant causal relationship between PP and all the elements of $\mathrm{BE}$ of the online stores. In physical stores case a large number of studies have indicated that repeated or long term use of PPs have adverse effect on some of the elements of BE (Winer, 1986 and Rahmani, Mojavery \& Allahbakhsh, 2012).

However, the current study has provided a new insight that PP in case of online stores positively and significantly effects all the elements of $\mathrm{BE}$. The results of the study 
support the view that the Online Stores may continue using repeated PP bursts to improve their sales and simultaneously improving their BE.

The study has made very important contribution in evaluating the mediating role played by $\mathrm{PQ}$ and BA on the contribution of PP on BL and BAsso. The study has clearly identified the significant role played by the two mediating variables, PQ and BA. Thus, the organizations that have high $\mathrm{PQ}$ will be able to improve BL and BAsso, while increasing its sales through price promotion. Similarly, higher BA also provides opportunity to the organization to utilize PP for sales improvement and simultaneously improve BL and BAsso.

\section{REFERENCES}

Aaker D A (1991), Managing Brand Equity, Free Press, New York.

Abbas, S.(2019).Brand loyalty of highereducation institutions. Marketing and management of innovations, 46-56

Agarwal, S., \&Teas, R.K.(2002). Crossnationalapplicability of a perceivedqualitymodel. Journal of Product and Brand Management, 11(4), 213-236. doi: 10.1108/10610420210435425

Agrawal, D.(1996). Effect of brandloyalty on advertising and tradepromotions: Agametheoreticanalysis with empiricalevidence. Marketing Science, 15(1), 86108. doi: $10.1287 /$ mksc.15.1.86.

Alba, J. W., Mela, C. F., Shimp, T. A., \&Urbany, J.(1999). The effect of discountfrequency and depth on consumerpricejudgments. Journal of Consumer Research, 26(2), 99-114. doi: 10.1086/209553

Alexandris, K., Douka, S., Papadopoulos, P., \&Kaltsatou, A.(2008). Testing the role of service quality on the development of brand associations and brand loyalty. Managing Service Quality, 18(3), 239-254. doi: 10.1108/09604520810871865.

Alexandris, K., Douka, S., Papadopoulos, P., \&Kaltsatou, A.(2008). Testing the role of service quality on the development of brand associations and brand loyalty. Managing Service Quality, 18(3), 239-254. doi: 10.1108/09604520810871865
Alhaddad, A.(2015). Perceived quality, brandimage and brandtrust as determinants of brandloyalty. Journal of Research in Business and Management [Online]. ISSN, 3(4), 01-08 (pp. 2347-3002)

Allender, W. J., \&Richards, T. J.(2012). Brand loyalty and pricepromotionstrategies: Anempiricalanalysis. Journal of Retailing. Elsevier, 88(3), 323-342. doi: 10.1016/j.jretai.2012.01.001.

Allender, W., \&Richards, T.(2009). Measures of Brand loyalty. Selected Paper prepared for presentation at the Agricultural and Applied Economics Association Joint Annual Meeting. Milwaukee, WI.

Anderson, E.T., \&Kumar, N.(2007). Price competition with repeat, loyalbuyers. Quantitative Marketing and Economics, 5(4), 333359. doi: 10.1007/s11129-007-9023-7.

Ardestani, A. S., Mirabi, V. R., Kazemi, M. A. A., \&Far, B. E.(2014). A study on the effect of marketing advertisements and price promotions to brand equity in Iranian insurance industry (a case study on Iran, Asia and Persian insurance companies). Research Journal of Recent Sciences, 3(7), 123-129.

Ardestani, A. S., Reza Mirabi, V., \&Afshar, M. A.(2014), A Study on the Effect of Marketing Advertisements and Price Promotions to Brand equity in Iranian Insurance Industry (A Case Study on Iran, Asia and Parsian Insurance Companies)Research Journal of Recent Sciences July. Kazemi1 and BehnamEsmaeili Far, 3(7),123-129,

Assunção, J. L., \&Meyer, R. J.(1993). The rationaleffect of pricepromotions on sales and consumption. Management Science, 39(5), 517535. doi: $10.1287 /$ mnsc.39.5.517

Bagozzi, R. P., \&Yi, Y.(1988). On the evaluation of structuralequationmodels. Journal of the Academy of Marketing Science, 16(1), 74-94. doi: 10.1007/BF02723327.

Bagwell, K., \&Riordan, M.(1991). High and decliningpricessignalproductquality. American Economic Review, 81(1), 224-239.

Bawa, K., \&Shoemaker, R. W.(1987). The effects of a directmailcoupon on brandchoicebehavior. Journal of Marketing Research, 24(4), 370-376. doi: $10.1177 / 002224378702400404$. 
Beavers, G. A., Iwata, B. A., \&Lerman, D. C. (2013). Thirty years of research on the functional analysis of problem behavior. Journal of Applied Behavior Analysis, 46(1), 1-21. doi: 10.1002/jaba.30. PubMed: 24114081

Beneke, J., Flynn, R., Greig, T., \& Mukaiwa, M. (2013). The influence of perceived product quality, relative price and risk on customer value and willingness to buy: a study of private label merchandise. Journal of Product $\mathcal{E}$ Brand Management, 22 (3), 218-228

Bravo Gil, R., Fraj Andrés, E., \&Martínez Salinas, E.(2007). Family as a source of consumer-based brand equity. Journal of Product and Brand Management, 16(3), 188-199. doi: 10.1108/10610420710751564

Bravo Gil, R., Fraj Andrés, E., \&Martínez Salinas, E.(2007). Family as a source of consumer based brand equity. Journal of Product and Brand Management, 16(3), 188-199. doi: $10.1108 / 10610420710751564$.

Buditama, W. S., \& Aksari, N. A. (2017). The Role of Perceived Quality Mediates the Perceived Price of Perceived Value Users of Jimbaran Boarding House Service Users. Eud Management E-Journal, 6 (2), 1055-1082.

Buil, I. B., de Chernatony, L., \&Leslie, E.(2010). The effect of advertising and salespromotions on brandequity. Therapeutic 6 th thought leaders in BRAND management international conference(p. 14).

Buil, I., de Chernatony, L. D., \& Martínez, E.(2013). Examining the role of advertising and sales promotions in brand equity creation. Journal of Business Research, 66(1), 115-122. doi: 10.1016/j.jbusres.2011.07.030.

Campo, S., \&Yagüe, M. J.(2008). Research note: Effects of price on touristsatisfaction. Tourism Economics, 14(3), 657-661. doi: $10.5367 / 000000008785633596$

Carmines, E.G., \&Zeller, R.A.(1979). Reliability and validityassessment. doi: 10.4135/ 9781412985642. SAGE Publications

Chan, Y.S., \&Leland, H.(1982). Price and qualities in marketswithcostlyinformation. Review of Economic Studies, 49(4), 499-516. doi: $10.2307 / 2297283$.

Chen, T. Y., Yeh, T. L., \&Jheng, W. S.(2013). Factors influencing brand association. African Journal of Business Management, 7(19), 19141926
Chen, T.-Y., Yen, T.-L., \&Jheng, W.-S.(2013). Factors influencing brand association. African Journal of Business Management, 7(19), 19141926. doi: 10.5897/AJBM11.2462

Chin, W. W., \&Marcoulides, G.(1998). The partialleast squaresapproach to structuralequationmodeling. Advances in Hospitality and Leisure, 8(2), 295-336

Chinomona, R., \&Maziriri, E. T.(2017). The influence of brand awareness, brand association and product quality on brand loyalty and repurchase intention: A case of male consumers for cosmetic brands in South Africa. Journal of Business and Retail Management Research, 12(1), 143-154. doi: 10.24052/Jbrmr/V12is01/Tiobabaapqoblariac omcfcbisa

Christodoulides G and De Chernatony L (2010), “Consumer-Based Brand Equity Conceptualization and Measurement: A Literature Review", International Journal of Market Research, Vol. 52, No. 1, pp. 43-66.

Chu, S., \&Keh, H. T.(2006). Brand value creation: Analysis of the inter brand -Business Week brand value rankings. Marketing Letters, 17(4), 323-331. doi: 10.1007/s11002-006-9407-6.

Conway, J. M., \& Huffcutt, A. I.(2003). A review and evaluation of exploratory factor analysis practices in organizational research. Organizational Research Methods, 6(2), 147-168. doi: $10.1177 / 1094428103251541$.

Cooper, R., \&Ross, T.W.(1984). Prices, productqualities and asymmetricinformation: Thecompetitivecase. Review of Economic Studies, 51(2). doi:10.2307/2297687

Correia Loureiro, S. M.(2013). The effect of perceivedbenefits, trust, quality, brandawareness, brandassociations and brandloyalty on internetbankingbrandequity. International Journal of Electronic Commerce Studies, 4(2), 139-158. doi: 10.7903/ijecs.1000

Cotton, B. C., \& Babb, E. M. (1978). Consumer response to promotionaldeals. Journal of Marketing, 42(3), 109-113. doi: $10.1177 / 002224297804200319$.

Davis, S., Inman, J. J., \&McAlister, L.(1992). Promotion has a negative effect on brand evaluations-or does it? additional disconfirming evidence. Journal of Marketing Research, 29(1), 143-148. doi: $10.1177 / 002224379202900112$. 
DelVecchio, D., Henard, D. H., \&Freling, T. H.(2006). The effect of sales promotion on post-promotion brand preference: A metaanalysis. Journal of Retailing, 82(3), 203-213. doi: 10.1016/j.jretai.2005.10.001.

DelVecchio, D., Krishnan, H.S., \&Smith, D.C.(2007). Cents or percent?The effects of promotion framing on price expectations and choice. Journal of Marketing, 71(3), 158-170. doi: 10.1509/jmkg.71.3.158.

Dhurup, M., Mafini, C., \&Dumasi, T.(2014). The impact of packaging, price and brand awareness on brand loyalty: Evidence from the paint retailing industry. Acta Commercii, 14(1), 194-203. doi: 10.4102/ac.v14i1.194

Dhurup, M., Mafini, C., \&Dumasi, T.(2014). The impact of packaging, price and brand awareness on brand loyalty: Evidence from the paint retailing industry. Acta Commercii, 14(1), 1-9. doi: 10.4102/ac.v14i1.194

Dodds, W. B., Monroe, K. B., \&Grewal, D.(1991). Effects of price, Brand, and storeinformation on buyers'productevaluations. Journal of Marketing Research, 28(3), 307-319. doi: 10.1177/002224379102800305

Dwivedi A and Johnson L W (2012), "TrustCommitment as a Mediator of the Celebrity Endorser-Brand Equity Relationship in a Service Context", Australasian Marketing Journal (AMJ), Vol. 21, No. 1, pp. 36-42.

Ehrenberg, A. S., Hammond, K., \&Goodhardt, G.(1994). The after-effects of price-related consumer promotions. Journal of Advertising Research, 34, 11-21.

Eisman, R.(1990). Building brandloyalty. Incentive Marketing, 164(9), 39-45

Erdem, T., Swait, J., \&Louviere, J.(2002). The impact of brand credibility on consumer price sensitivity. International Journal of Research in Marketing, 19(1), 1-19. doi: 10.1016/S01678116(01)00048-9

Eugine TafadzwaMaziriri, R. C.(2017). The influence of brand awareness, brand association and product quality on brand loyalty and repurchase intention: A case of male consumers for cosmetic brands in South Africa. Journal of Business and Retail Management Research (JBRMR), 12(1), 143-154.

Fabrigar, L. R., Wegener, D. T., MacCallum, R. C., \&Strahan, E. J.(1999). Evaluating the use of exploratory factor analysis in psychological research. Psychological Methods, 4, 989x.4.3.272, 272-299. doi:10.1037/1082

Mohammad Falahat, Chong Shyue Chuan, Sia Bik Kai (2018). Brand Loyalty and Determinates of Perceived Quality and Willingness to Order. Academy of Strategic Management Journal, 17(4), pp1-10

Faircloth J B, Capella L M and Alford B L (2001), "The Effect of Brand Attitude and Brand Image on Brand Equity", Journal of Marketing Theory and Practice, Vol. 9, No. 3, pp. 61-75.

Fco, Á., \&Villarejo-Ramos, M. J. S.-F.(2005). Marketing Communication as a precedent for Brand Equity: An Examination into the Market of Durable Products. Brand Management, 12(6), 431-444

Fornell, C., \&Larcker, D. F.(1981). Evaluating structuralequationmodels with unobservablevariables and measurementerror. Journal of Marketing Research, 18(1), 39-50. doi: 10.1177/002224378101800104.

Gilbert, D.C., \&Jackaria, N.(2002). The efficacy of sales promotions in UKsuper markets: A consumer view. International Journal of Retail and Distribution Management, 30(6), 315-322. doi: 10.1108/09590550210429522.

Gill M S and Dawra J (2010), “Evaluating Aaker's Sources of Brand Equity and the Mediating Role of Brand Image", Journal of Targeting, Measurement and Analysis for Marketing, Vol. 18, No. 3, pp. 189-198.

Haigh D (1999), "Understanding the Financial Value of Brands", available at: http:/ / citeseerx.ist.psu.edu/viewdoc/download?do $i=10.1 \cdot 1.199 .8159 \& r e p=r e p 1 \& t y p e=p d f$.

Accessed on September 20, 2013.

Hendra, Pratama and Budi, Suprapto (2017). The Effect of Brand Image, Price, and Brand Awareness on Brand Loyalty: The Rule of Customer Satisfaction as a Mediating Variable. Global Journal of Business \& Social Science Review, 5(2), pp. 52-57, Available at SSRN: https:// ssrn.com/abstract $=3002424$

Homburg, C., Klarmann, M., \&Schmitt, J.(2010). Brand awareness in business markets: When is it related to firm performance?International Journal of Research in Marketing, 27(3), 201-212. doi: 10.1016/j.jiresmar.2010.03.004 
Hosken, D., \&Reiffen, D.(2004). How retailersdeterminewhichproductsshouldgo on sale: Evidence from store-leveldata. Journal of Consumer Policy, 27(2), 141-177. doi: 10.1023/B:COPO.0000028171.70221.f3.

Hu, L. T., \&Bentler, P. M.(1999). Cutoff criteria for fit indexes in covariance structure analysis: Conventional criteria versus new alternatives. Structural Equation Modeling: A Multidisciplinary Journal,6(1), 1-55. doi: 10.1080/10705519909540118.

Huang, H., Chang, Y., Yeh, C., \&Liao, C.(2014). Promote the price promotion. International Journal of Contemporary Hospitality Management, 26(7), 1065-1082. doi: 10.1108/IJCHM-05-20130204 .

Huff, L. C., \&Alden, D. L.(2000). A model of managerial response to sales promotions: A four-country analysis. Journal of Global Marketing, 13(3), 7-28. doi: 10.1300/J042v13n03_02

Hussain, S., Ahmed, W., Jafar, R. M. S., Rabnawaz, A., \&Jianzhou, Y.(2017). eWOM source credibility, perceived risk and food product customer's information adoption. Computers in HumanBehavior, 66, 96102. doi: $10.1016 /$ j.chb.2016.09.034

Jedidi, K., Mela, C. F., \&Gupta, S.(1999). Managing advertising and promotion for longrunprofitability. Marketing Science, 18(1), 1-22. doi: $10.1287 /$ mksc.18.1.1

Jing, B., \&Wen, Z.(2008). Finitely loyalcustomers, switchers, and equilibriumpricepromotion. Journal of Economics and Management Strategy, 17(3), 683707. doi: 10.1111/j.1530-9134.2008.00191.x.

Jing, Z., Pitsaphol, C., and Shabbir, R. (2014).The Association of Brand Equity Dimension and Market Share: A Case Study of Smartphone in Thailand. Journal of Economics and Sustainable Development, 5(21), 100-106

Kalyanaram, G., \&Winer, R. S.(1995). Empirical generalizations from referencepriceresearch. Marketing Science, 14(3_supplement), G161-G169. doi: 10.1287/mksc.14.3.G161

Keller K L (1993), “Conceptualizing, Measuring and Managing Customer-Based Brand Equity", Journal of Marketing, Vol. 57, No. 1, pp. 1-22.
Kim K H, Kim K S, Kim D Y et al. (2008), "Brand Equity in Hospital Marketing", Journal of Business Research, Vol. 61, No. 1, pp. 75-82.

Kirmani, A., \&Rao, A. R.(2000). No pain, nogain: Acriticalreview of the literature on signalingunobservableproductquality. Journal of Marketing, 64(2), 66-79. doi:10.1509/jmkg.64.2.66.18000

KIEU, Anh Tai (2016). The Impact of Brand Relationship and Perceived Quality on Brand Loyalty in the Emerging Market Context of Vietnam. Unpublished PhD Thesis submitted to University of Western Sydney.

Klein, B., \& Leffler, K. B.(1981). The role of market forces in assuring contractual performance. Journal of Political Economy, 89(4), 615-641. doi: 10.1086/260996.

Klenke, K.(2008). Qualitative research in the study of leadership. Bingley, UK: Emerald Group.

Koçaş, C., \&Bohlmann, J.D.(2008). Segmented switchers and retailerpricingstrategies. Journal of Marketing, 72(3), 124-142. doi: 10.1509/JMKG.72.3.124.

Konecnik M and Gartner W C (2007), "Customer-Based Brand Equity for a Destination", Annals of Tourism Research, Vol. 34, No. 2, pp. 400-421.

Kuehn, A. A., \&Rohloff, A. C.(1967). Consumer response to premiums. In P.Robinson (Ed.). Promotional decisionusingmathematicalmodels. Boston: Allyn \& Bacon.

Kuntner, T.(2017). Price promotions and brand equity: The role of brand types. [ZBW-Deutsche Zentralbibliothek für Wirtschaftswissenschaften]. Kiel, Hamburg: Leibniz Information Centre for Economics.

Lance, C. E., Butts, M. M., \&Michels, L. C.(2006). The sources of fourcommonlyreportedcutoffcriteriawhatdidt hey Really say?Organizational Research Methods, 9(2), 202-220. doi: $10.1177 / 1094428105284919$.

Lattin, J. M., \&Bucklin, R. E.(1989). Reference effects on price and promotion on brandchoice. Journal of Marketing Research, 26(August), 299-310.

Lim, W.M., \&Ting, D.H.(2012). E-shopping: An analysis of the Technology Acceptance 
Model. Modern Applied Science, 6(4), 49-62. doi: 10.5539/mas.v6n4p49

Lohmöller, J. B.(1989).Latent variable path modeling with partial least squares. Heidelberg: Physica Verlag.

Loureiro, S.M.C.(2013). The effect of perceived benefits, trust, quality, brand awareness/associations and brand loyalty on internet banking brand equity. International Journal of Electronic Commerce Studies, 4(2), 139158. doi: 10.7903/ijecs.1000

Madan,V., \&Suri, R.(2001). Quality perception and monetary sacrifice: A comparative analysis of discount and fixed prices. Journal of Product and Brand Management, 10(3), 170-184. doi: 10.1108/10610420110395395.

Malik, Muhammad Ehsan, Ghafoor, Muhammad Mudasar, Iqbal, Hafiz Kashif (2013). Importance of Brand Awareness and Brand Loyalty in Assessing Purchase Intentions of Consumer. International Journal of Business and Social Science, 4(5), pp 167-171.

Marcel, A. R. (2009). The Effect of the Marketing Communication and price Promotion towardBrand Equity. Business and Entrepreneurial Review, 9(1), 41-50. doi: 10.25105/ber.v9i1.27.

Marquardt A J (2013), “Relationship Quality as a Resource to Build Industrial Brand Equity When Products are Uncertain and FutureBased", Industrial Marketing Management, Vol. 42, No. 8, pp. 1386-1397.

Mayhew, G. E., \&Winer, R. S.(1992). An empiricalanalysis of internal and externalreferenceprices using scannerdata. Journal of Consumer Research, 19(1), 62-71. doi: $10.1086 / 209286$.

Mela, C. F., Jedidi, K., \&Bowman, D.(1998). The long-term impact of promotions on consumer stockpiling. Journal of Marketing Research, 35(2) (May), 250-262

Melina, A., \&Evelyn, H.(2011). The effect of marketing communication and price promotion to brand equity, the. 2ndinternational research symposium in service management, Jogakarta. Indonisia

Milgrom, P., \&Roberts, J.(1986). Price and advertisingsignals of productquality. Journal of Political Economy, 94(4), 796-821. doi: $10.1086 / 261408$
Moreira de Morais, J., David Henrique dos Santos, O. D., Delicato, T., Azzini Gonçalves, R., \& Alves da Rocha-Filho, P. (2006). Physicochemical Characterization of Canola oil-waternano-emulsions Obtained by Determination of Required HLB Number and Emulsion Phase Inversion Methods. Journal of Dispersion Science and Technology, 27(1), 109115. doi: 10.1081/DIS-200066829

Muhammad Ehsan, M., Mudasar Ghafoor, M., Iqbal, H. K., Riaz, U., ul Hassan, N., Mustafa, M., \&Shahbaz, S.(2013). Importance of Brand Awareness and Brand Loyalty in assessing Purchase Intentions of Consumer. International Journal of Business and Social Science, 4(5), 167171.

Mullin, R., \&Cummins, J.(2008). Sales promotion: How to create, implement and integratecampaigns that Really work (4thed). London: Kogan Page

Neslin, S. A., \& Shoemaker, R. W. (1989). An alternative explanation for lowerrepeat ratesaf ter promotion purchases. Journal of Marketing Research, 26(2), 205-213. doi: $10.1177 / 002224378902600206$.

Nunnally, J.C.(1978). Psychometric theory. New York, NY: McGraw-Hill

Nurcahya, K. E.(2014). The Impact of Perceived Advertising Spending and Price Promotion on Brand Equity: A Case of ABC, Brand.iBuss Management, 2(2), 133-144.

Nurcahya, K. E.(2014). The impact of perceived advertising spending and price promotion on brand equity: $\mathrm{A}$ case of $\mathrm{ABC}$ brand. iBuss Management, 2(2), 133-144

Oh, Haemoon (2000). The Effect of Brand Class, Brand Awareness and Price on Customer Value and Behavioral Intentions. Journal of Hospitality and Tourism Research, 24(2), pp. 136-162.

Oude Ophuis, P. A. M., \&Van Trijp, H. C. M.(1995). Perceived quality: A market driven and consumer-oriented approach. Food Quality and Preference, 6(3), 177-183. doi: 10.1016/09503293(94)00028-T.

Palazn-Vidal, M., \&Delgado-Ballester, E.(2005). Sales promotions effects on consumer-based brand equity. International Journal of Market Research, 47(2), 179-204. Retrieved from 
http://www.sciencedirect.com/science/journ al/01678116. doi: 10.1177/147078530504700205

Perry, B. D.(2001). The neuroarcheology of childhood maltreatment: The neurodevelopmental costs of adverse childhood events. In K.Franey, R.Geffner\&R.Falconer (Eds.), The cost of maltreatment: Who pays? We all do (pp. 15-37). Binghamton, NY: Haworth Press

Piratheepan, U., \&Pushpanathan, A.(2013). Impact of promotionalstrategies on brandawareness: Astudy on milkpowderbrands in Nuwaraeliya District. IFRSA Business Review, 3(4), 268-272

Pressey, A., \&Mathews, B.(1998). Relationship marketing and retailing: Comfortable bedfellows?International Journal of Customer Relationships Management, 1(1), 39-52.

Raghubir, P., \&Corfman, K. P.(1999). When dopricepromotionsaffectpretrialbrandevaluati ons?Journal of Marketing Research, 36(2), 211222. doi: $10.1177 / 002224379903600206$

Rahmani, Z., Mojaveri, H.S., \&Allahbakhsh, A.(2012). Review the impact of advertising and salepromotion on brandequity. Journal of Business Studies Quarterly, 4(1), 64-73.

Raju, J.S., Srinivasan, V., \&Lal, R.(1990). The effects of brandloyalty on competitivepricepromotionalstrategies.

Management Science, 36(3), 276-304. doi: 10.1287/mnsc.36.3.276.

Rao, A. R., \&Monroe, K. B.(1989). The effect of price, brand name, and store name on buyers. perceptions of product quality: An integrative review. Journal of Marketing Research, 26(3), 351-357. doi: $10.1177 / 002224378902600309$

Rao, R.C.(1991). Pricing and promotions in asymmetricduopolies. Marketing Science, 10(2), 131-144. doi: 10.1287/mksc.10.2.131.

Rogelberg, S.G.(2002). Handbook of researchmethods in industrial and Organizational Psychology. Oxford: Blackwell Publishing.

Rothschild, M. L., \&Gaidis, W. C.(1981). Behavioral learningtheory: Itsrelevance to marketing and promotions. Journal of Marketing, 45(spring), 70-78.

Rungtrakulchai, R.(2015). Price promotions and brandequity: Thecase of luxurybrands. Global Fashion Management Conference. Global fashionmanagementconference at Florence proceedings, $\quad 1(4), \quad 76-88 . \quad$ doi: 10.15444/GFMC2015.01.04.03

Rungtrakulchai, R.(2015). Price Promotions and Brand Equity: The Case of Luxury brands. Retrieved from http://dx.doi.org/10.15444/GFMC2015.01.04. 03. Global fashionmanagementconference at Florence proceedings (pp. 76-88)

Saif, M. A., Zefreh, M. M., \&Torok, A.(2019). Public transportaccessibility: AliteraturereviewMuhammad. Periodica Polytechnica Transportation Engineering, 47(1), 36-43. doi: 10.3311/PPtr.12072

Saif, T., Ahmed, M., Shareef, S., \&Khalid, R.(2018). Characteristics of brandloyalty: Astudy on apparelindustry. Mediterranean Journal of Basic and Applied Sciences (MJBAS), 2(2), 64-69

Erfan Severi \& Kwek Choon Ling (2013). The Mediating Effects of Brand Association, Brand Loyalty, Brand Image and Perceived Quality on Brand Equity. Asian Social Science, 9(3), 125-137.

Salelaw, G.T., \&Singh, A.(2016). The impact of salespromotion on brandequity: Thecase of breweryindustry. Journal of Marketing and Consumer Research, 22, 68-81, ISSN 2422-8451

Selvakumar, J. J., \&DrVikkraman, P.(2011). Impact of advertising and price promotions on brand equity in service sector. Journal of Contemporary Research in Marketing, 6(3), 51-65.

Shintaputri, Ikaningrum, and Amelinda J. Wuisan (2017). The Impact of Perceived Price towards Perceived Value through the Mediation of Perceived Quality: a Case of Brand X Smartphone in Indonesian MiddleClass Customers. iBuss Management, 5(1), pp29-42.

Sinha A, Gazley A and Ashill N J (2008), "Measuring Customer Based Brand Equity Using Hierarchical Bayes Methodology", Australasian Marketing Journal (AMJ), Vol. 16, No. 1, pp. 3-19.

Sriram, S., Balachander, S., \&Kalwani, M. U. (2007). Monitoring the dynamics of brand equity using store-level data. Journal of Marketing, 71(april), 61-78.

Stibel, J.(2008). In a downturn, discounts can be dangerous. Harvard Business Review. Retrievedfromhttps://hbr.org/2008/08/in-adownturn-discounts-can-be. 
Syed Ali, A.(2018). Comparative Analysis of Brand Awareness and Service Quality in effective Brand Loyalty of Higher Education Institutions. International conference on socialscience, humanities and education.

Tebebe, S. G., \&Singh, A.(2016). The impact of salespromotion on brandequity: Thecase of breweryindustry. Journal of Marketing and Consumer Research, 22, 68-81

$\mathrm{Xu}$, Fengzeng \& Li, Yunhe \& Zhou, Jian. (2015). Brand Awareness for Entrepreneurial Hotel Chains: Perceived Quality and Brand Loyalty. Anthropologist, 19. 763-771. 10.1080/09720073.2015.11891712.

Villarejo, A. F., Rondan, F. J., \&Sanchez, M. J.(2008). Directand indirect effects of marketing effort on brand awareness and brand image, https://www.researchgate.net /publication/283293566. Conference. 7th internationalcongress of marketingtrends, At: Venice (Italy)

Villarejo-Ramos, A. F., \&Sánchez-Franco, M. J.(2005). The impact of marketing communication and price promotion on brand equity. Journal of Brand Management, 12(6), 431444. doi: 10.1057/ palgrave.bm. 2540238

Villarejo-Ramos, A. F., \&Sánchez-Franco, M. J.(2005).The impact of marketing communication and price promotion on brand equity. Journal of Brand Management, 12(6), 431444. doi: $10.1057 /$ palgrave.bm. 2540238

Villarejo-Ramos, A.F., \&Sánchez-Franco, M.J.(2005). The impact of marketing communication and price promotion on brand equity. Journal of Brand Management, 12(6), 431444. doi: 10.1057/palgrave.bm.2540238.

Villarejo-Ramos, A., Rondán-Cataluña, F., \&SánchezFranco, M.(2005). Direct and indirect effects of marketing effort on brand awareness and brand image.Marketing Letters, 11(3), 221233.

Waanders, Koen(2013). The effectiveness and consequences of price promotions [MastersThesis], master of Communication Studies. Twente: Faculty of Behavioral Sciences, University of Twente

Winer, R.S.(1986). A reference price model of brand choice for frequently purchased products. Journal of Consumer Research, 13(2), 250-256. doi: 10.1086/209064.

Winer, R. S.(1986). A referencepricemodel of brandchoice for frequentlypurchasedproducts. Journal of Consumer Research, 13(2), 250-256. doi: 10.1086/209064.

Wixom, B. H., \&Watson, H. J.(2001). AnEmpiricallnvestigationoftheFactorsaffecting Data Warehousing Success. MIS Quarterly, 25(1), 17-41. doi: 10.2307/3250957.

Yoo, B., Donthu, N., \&Lee, S.(2000). An examination of selected marketing mix elements and brand equity. Journal of the Academy of Marketing Science. Academy of Marketing Science, 28(2), 195-211. doi: 10.1177/0092070300282002.

Zeinolabedin Rahmani, P., Mojaveri, H.S., Allahbakhsh, A., \&Payame(2012). Review the impact of advertising and salepromotion on brandequity. Journal of Business Studies Quarterly, 4(1), 64-73

Zarantonello L and Schmitt B (2012), "The Impact of Event Marketing on Brand Equity: The Mediating Roles of Brand Experience and Brand Attitude", International Journal of Advertising, Vol. 32, No. 2, pp. 255-280. 
Tables

Table 1: Showing Reliability Analysis

\begin{tabular}{|c|l|c|c|}
\hline S. No. & Variable Name & Cronbach's Alpha & No. of items \\
\hline 1 & Perceived Quality & 0.841 & 3 \\
\hline 2 & Brand Loyalty & 0.792 & 4 \\
\hline 3 & Brand Awareness & 0.813 & 5 \\
\hline 4 & Brand Association & 0.813 & 3 \\
\hline 5 & Price Promotion & 0.809 & 4 \\
\hline
\end{tabular}

Table 2: Showing KMO and Bartlett's Test results

\begin{tabular}{|l|l|l|l|l|}
\hline S. No. & Variable Name & \multirow{2}{*}{ KMO Value } & \multicolumn{2}{|c|}{ Bartlett's Test } \\
\cline { 4 - 5 } & & & Chi Square Value & Sig. \\
\hline 1 & Perceived Quality & 0.726 & 393.374 & .000 \\
\hline 2 & Brand Loyalty & 0.780 & 368.084 & .000 \\
\hline 3 & Brand Awareness & 0.828 & 520.710 & .000 \\
\hline 4 & Brand Association & 0.714 & 327.410 & .000 \\
\hline 5 & Price Promotion & 0.794 & 407.833 & .000 \\
\hline
\end{tabular}

Table 3: Showing Indices for Model Fit

\begin{tabular}{|l|r|r|}
\hline & Saturated Model & Estimated Model \\
\hline SRMR & 0.059 & 0.085 \\
\hline d_ULS & 0.672 & 1.367 \\
\hline d_G & 0.287 & 0.329 \\
\hline Chi-Square & 540.640 & 563.976 \\
\hline NFI & 0.917 & 0.909 \\
\hline RMS Theta & & 0.158 \\
\hline
\end{tabular}

Table 4: The Outer Loadings for the Conceptual Model

\begin{tabular}{|c|c|c|c|c|c|}
\hline & $\begin{array}{l}\text { Brand } \\
\text { Association }\end{array}$ & $\begin{array}{l}\text { Brand } \\
\text { Awareness }\end{array}$ & $\begin{array}{l}\text { Brand } \\
\text { Loyalty }\end{array}$ & $\begin{array}{l}\text { Perceived } \\
\text { Quality }\end{array}$ & $\begin{array}{l}\text { Price } \\
\text { Promotion }\end{array}$ \\
\hline BA1 & & 0.793 & & & \\
\hline BA2 & & 0.813 & & & \\
\hline BA3 & & 0.775 & & & \\
\hline BA4 & & 0.733 & & & \\
\hline BA5 & & 0.683 & & & \\
\hline BAA1 & 0.870 & & & & \\
\hline BAA2 & 0.843 & & & & \\
\hline BAA3 & 0.846 & & & & \\
\hline BL1 & & & 0.813 & & \\
\hline BL2 & & & 0.812 & & \\
\hline BL3 & & & 0.752 & & \\
\hline BL4 & & & 0.759 & & \\
\hline PP1 & & & & & 0.817 \\
\hline PP2 & & & & & 0.800 \\
\hline PP3 & & & & & 0.777 \\
\hline PP4 & & & & & 0.800 \\
\hline PQ1 & & & & 0.891 & \\
\hline PQ2 & & & & 0.856 & \\
\hline PQ3 & & & & 0.867 & \\
\hline
\end{tabular}


Table 5: Showing the Composite Reliabilities

\begin{tabular}{|l|c|c|c|c|}
\hline & Cronbach's Alpha & rho_A & $\begin{array}{c}\text { Composite } \\
\text { Reliability }\end{array}$ & $\begin{array}{c}\text { Average Variance } \\
\text { Extracted (AVE) }\end{array}$ \\
\hline Brand Association & 0.813 & 0.814 & 0.889 & 0.728 \\
\hline Brand Awareness & 0.817 & 0.818 & 0.873 & 0.579 \\
\hline Brand Loyalty & 0.791 & 0.793 & 0.865 & 0.616 \\
\hline Perceived Quality & 0.842 & 0.846 & 0.904 & 0.759 \\
\hline Price Promotion & 0.810 & 0.811 & 0.876 & 0.638 \\
\hline
\end{tabular}

Table 6: Showing the Discriminant Validity (Farnell - Larker Criterion) for first Conceptual Model

\begin{tabular}{|l|c|c|c|c|c|}
\hline & $\begin{array}{c}\text { Brand } \\
\text { Association }\end{array}$ & $\begin{array}{c}\text { Brand } \\
\text { Awareness }\end{array}$ & $\begin{array}{c}\text { Brand } \\
\text { Loyalty }\end{array}$ & $\begin{array}{c}\text { Perceived } \\
\text { Quality }\end{array}$ & $\begin{array}{c}\text { Price } \\
\text { Promotion }\end{array}$ \\
\hline Brand Association & $\mathbf{0 . 8 5 3}$ & & & & \\
\hline Brand Awareness & 0.701 & $\mathbf{0 . 7 6 1}$ & & & \\
\hline Brand Loyalty & 0.586 & 0.638 & $\mathbf{0 . 7 8 5}$ & & \\
\hline Perceived Quality & 0.590 & 0.627 & 0.680 & $\mathbf{0 . 8 7 1}$ & \\
\hline Price Promotion & 0.614 & 0.641 & 0.569 & 0.585 & $\mathbf{0 . 7 9 9}$ \\
\hline
\end{tabular}

Table 7: Showing the t-test values for testing the strength of relationship between variables

\begin{tabular}{|c|l|l|l|l|l|l|l|}
\hline Hypotheses & Relationship & $\begin{array}{l}\text { Path } \\
\text { Coefficients }\end{array}$ & $\begin{array}{l}\text { Sample } \\
\text { Mean }\end{array}$ & $\begin{array}{l}\text { Standard } \\
\text { Deviation }\end{array}$ & $\begin{array}{l}\text { T } \\
\text { Statistics }\end{array}$ & P Values & Remarks \\
\hline $\mathrm{H}_{1}$ & PP -> BAsso & 0.614 & 0.622 & 0.056 & 10.920 & $\mathbf{0 . 0 0 0}$ & Supported \\
\hline $\mathrm{H}_{2}$ & PP -> BA & 0.641 & 0.645 & 0.059 & 10.872 & $\mathbf{0 . 0 0 0}$ & Supported \\
\hline $\mathrm{H}_{3}$ & PP -> BL & 0.115 & 0.115 & 0.066 & 1.732 & $\mathbf{0 . 0 8 4}$ & Not Supported \\
\hline $\mathrm{H}_{4}$ & PP -> PQ & 0.251 & 0.253 & 0.067 & 3.728 & $\mathbf{0 . 0 0 0}$ & Supported \\
\hline $\mathrm{H}_{5}$ & PQ -> BL & 0.398 & 0.390 & 0.077 & 5.152 & $\mathbf{0 . 0 0 0}$ & Supported \\
\hline $\mathrm{H}_{6}$ & BAsso -> PQ & 0.214 & 0.221 & 0.075 & 2.859 & $\mathbf{0 . 0 0 4}$ & Supported \\
\hline $\mathrm{H}_{7}$ & BAsso -> BL & 0.117 & 0.123 & 0.067 & 1.737 & $\mathbf{0 . 0 8 3}$ & Not Supported \\
\hline $\mathrm{H}_{8}$ & BA -> BL & 0.233 & 0.233 & 0.082 & 2.831 & $\mathbf{0 . 0 0 5}$ & Supported \\
\hline $\mathrm{H}_{9}$ & BA -> PQ & 0.316 & 0.311 & 0.065 & 4.842 & $\mathbf{0 . 0 0 0}$ & Supported \\
\hline
\end{tabular}


Fig. 1: Showing the SEM dia with PLS computations

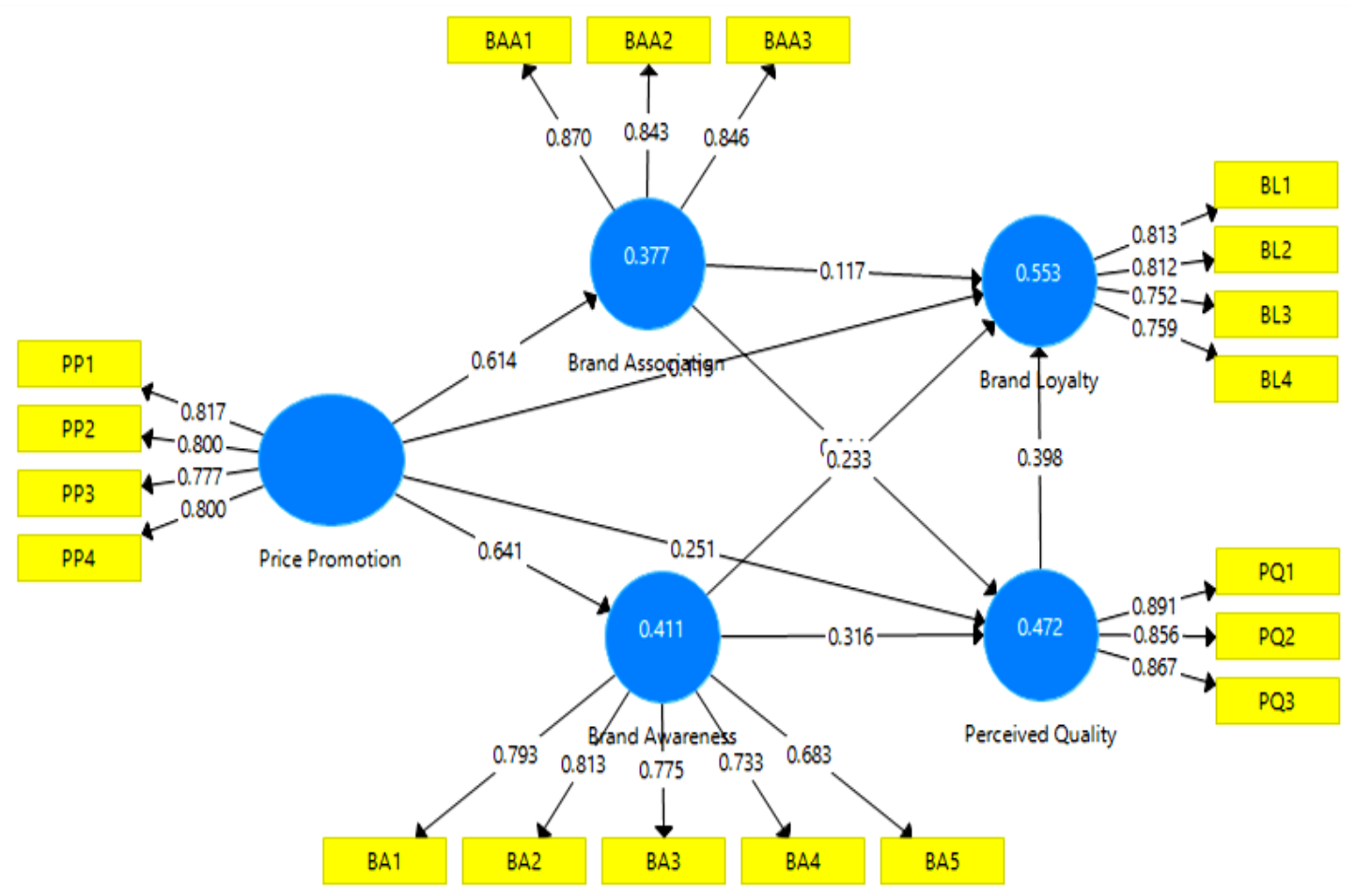

Figure 2: Showing Bootstrapped-' $t$ ' test values of the Model

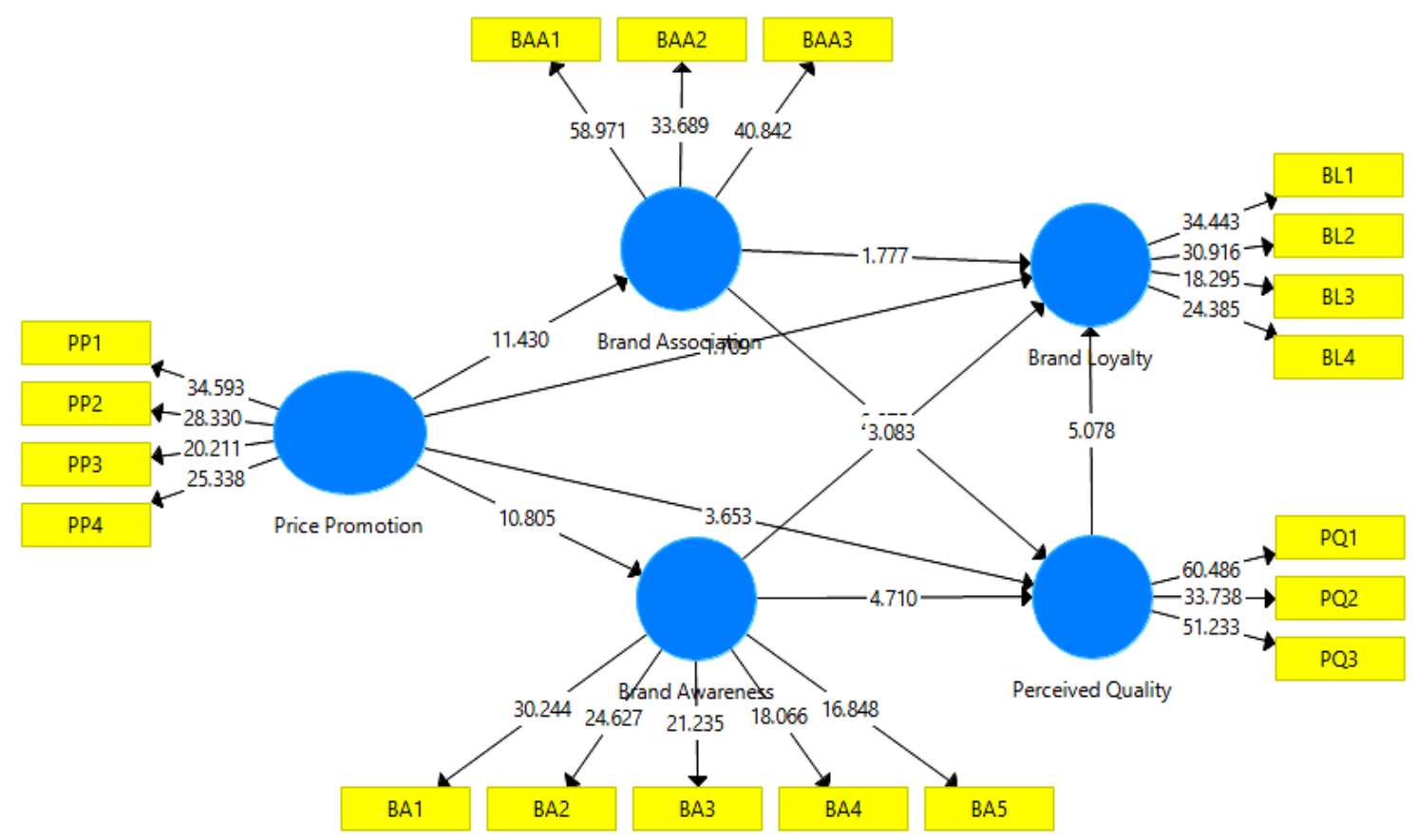

